Research article

\title{
The influence of solid retention time on IFAS-MBR systems: Assessment of nitrous oxide emission
}

\author{
Giorgio Mannina a , Marco Capodici a , Alida Cosenza ${ }^{a}{ }^{*}$, Vito Armando Laudicina ${ }^{\text {b }}$, \\ Daniele Di Trapani ${ }^{\text {a }}$ \\ a Dipartimento di Ingegneria Civile, Ambientale, Aerospaziale, dei Materiali, Università di Palermo, Viale delle Scienze, Ed. 8, 90128, Palermo, Italy \\ b Dipartimento di Scienze Agrarie e Forestali, Università di Palermo, Viale delle Scienze, Ed. 4, 90128, Palermo, Italy
}

\section{A R T I C L E I N F O}

Article history:

Received 24 April 2017

Received in revised form

21 July 2017

Accepted 5 August 2017

\section{Keywords:}

Nitrous oxide

IFAS-MBR

UCT

Activated sludge

Biofilm

Emission factor

\begin{abstract}
A B S T R A C T
The aim of the present study was to investigate the nitrous oxide $\left(\mathrm{N}_{2} \mathrm{O}\right)$ emissions from a moving bed based Integrated Fixed Film Activated Sludge (IFAS) - membrane bioreactor (MBR) pilot plant, designed according to the University of Cape Town (UCT) layout. The experimental campaign had a duration of 110 days and was characterized by three different sludge retention time (SRT) values ( $\infty, 30 \mathrm{~d}$ and $15 \mathrm{~d}$ ). Results highlighted that $\mathrm{N}_{2} \mathrm{O}$ concentrations decreased when the biofilm concentrations increased within the aerobic reactor. Results have shown an increase of $\mathrm{N}_{2} \mathrm{O}$ with the decrease of SRT. Specifically, an increase of $\mathrm{N}_{2} \mathrm{O}-\mathrm{N}$ emission factor occurred with the decrease of the SRT $(0.13 \%, 0.21 \%$ and $0.76 \%$ of influent nitrogen for SRT $=\infty$, SRT $=30 \mathrm{~d}$ and SRT $=15 \mathrm{~d}$, respectively). Moreover, the MBR tank resulted the key emission source (up to $70 \%$ of the total $\mathrm{N}_{2} \mathrm{O}$ emission during SRT $=\infty$ period) whereas the highest $\mathrm{N}_{2} \mathrm{O}$ production occurred in the anoxic reactor. Moreover, $\mathrm{N}_{2} \mathrm{O}$ concentrations measured in the permeate flow were not negligible, thus highlighting its potential detrimental contribution for the receiving water body. The role of each plant reactor as $\mathrm{N}_{2} \mathrm{O}-\mathrm{N}$ producer/consumer varies with the SRT variation, indeed the aerobic reactor was a $\mathrm{N}_{2} \mathrm{O}$ consumer at SRT $=\infty$ and a producer at SRT $=30 \mathrm{~d}$.
\end{abstract}

(C) 2017 Elsevier Ltd. All rights reserved.

\section{Introduction}

Nitrous Oxide $\left(\mathrm{N}_{2} \mathrm{O}\right)$ represents a significant greenhouse gas (GHG) with a global warming potential (GWP) 298 times higher compared to carbon dioxide $\left(\mathrm{CO}_{2}\right)$ (IPCC, 2007). Since many bacteria involved in biological nitrogen removal from wastewater are able to produce $\mathrm{N}_{2} \mathrm{O}$, in recent years $\mathrm{N}_{2} \mathrm{O}$ emission from wastewater treatment plants (WWTPs) has received increasing attention by the scientific community (Stenström et al., 2014; Ni and Yuan, 2015; Mannina et al., 2016a). $\mathrm{N}_{2} \mathrm{O}$ production mainly occurs during biological nutrient removal (BNR) processes (Kampschreur et al. 2009). Indeed, $\mathrm{N}_{2} \mathrm{O}$ can be produced by ammonia oxidizing bacteria (AOB) during nitrification (Peng et al., 2015). Furthermore, since $\mathrm{N}_{2} \mathrm{O}$ represents an intermediate product of the heterotrophic denitrification process, it can be produced via incomplete heterotrophic denitrification (Liu et al., 2015). Therefore, both autotrophic and heterotrophic bacteria can be responsible for $\mathrm{N}_{2} \mathrm{O}$ production

\footnotetext{
* Corresponding author.

E-mail address: alida.cosenza@unipa.it (A. Cosenza).
}

during BNR (Kampschreur et al., 2009; Chandran et al., 2011; Law et al., 2012; Paudel et al., 2015). Moreover, during phosphorus removal process, $\mathrm{N}_{2} \mathrm{O}$ production can also occur (Kampschreur et al., 2009; Zhou et al., 2012). Indeed, technical literature highlights that in processes aimed at biological nitrogen and phosphorous removal (BNPR), the role of polyphosphate accumulating organisms (PAOs) in the production of $\mathrm{N}_{2} \mathrm{O}$ cannot be disregarded (Zhou et al., 2012). Indeed, PAOs can growth under anoxic conditions by using nitrate and/or nitrite as the terminal electron acceptor to oxidize their intracellular Polyhydroxyalkanoate (PHA). Therefore, under certain conditions, $\mathrm{N}_{2} \mathrm{O}$ can be accumulated during the denitrification due to $\mathrm{PAO}_{S}$ activity (Zeng et al., 2003).

In the last years, several efforts have been dedicated to better understand the key mechanisms involved in $\mathrm{N}_{2} \mathrm{O}$ production and emission (Kampschreur et al., 2009). Several operational conditions and influent features that might favour $\mathrm{N}_{2} \mathrm{O}$ production/emission have been identified: low dissolved oxygen (DO) concentrations, nitrite accumulation, dynamic conditions as well as low carbon-tonitrogen $(\mathrm{C} / \mathrm{N})$ ratio values during denitrification (Kampschreur et al., 2009; Chiu and Chung, 2000; Park et al., 2000; Zeng et al., 2003; Tallec et al., 2008; Mannina et al., 2017a). Amongst the 
main operational variables, the sludge retention time (SRT) has been recognized able to influence $\mathrm{N}_{2} \mathrm{O}$ production. Indeed, previous studies carried out on full scale WWTP highlighted that the $\mathrm{N}_{2} \mathrm{O}$ production increases with the decrease of the SRT (Kampschreur et al., 2009). However, as authors are aware, most of the studies dealing with $\mathrm{N}_{2} \mathrm{O}$ production/emission are focused on conventional activated sludge (CAS) systems. This aspect must face with the spread-out of innovative technologies occurred during the last ten years (e.g., biofilm systems, membrane systems etc.).

Indeed, very recently hybrid systems, integrating biofilm within a suspended-growth system, have been proposed for BNPR (LeyvaDíaz et al., 2016). Hybrid systems have the advantages of maximizing the nitrification taking advantage of the high SRT of the biofilm, but having the potential of operating the suspended growth phase with a relatively short SRT. Moreover, in a hybrid system, biofilm and suspended biomass may have a different role referring to either nitrogen or phosphorus removal. This peculiar aspect can be of importance in terms of $\mathrm{N}_{2} \mathrm{O}$ emissions from BNPR in hybrid systems. Among the hybrid systems, the joint use of membrane bioreactors (MBRs) and moving bed biofilm reactors (MBBRs) was recently proposed, replacing the secondary settler by means of the membrane module. The latter configuration is usually referred to as MB-MBR (Di Trapani et al., 2014) or IFAS-MBR. Regarding the biofilm influence on $\mathrm{N}_{2} \mathrm{O}$ production, literature shows a very limited knowledge (Todt and Dörsch, 2015). Indeed, to author's knowledge, there are only few modelling studies that compare the relative effects of the biofilm and the suspended sludge on $\mathrm{N}$ and $\mathrm{P}$ removal efficiencies and $\mathrm{N}_{2} \mathrm{O}$ emission in a hybrid BNPR system. Sen et al. (2010) developed a model aimed at investigating the differences between MBBR-based Integrated Fixed Film Activated Sludge (IFAS) and CAS in producing $\mathrm{N}_{2} \mathrm{O}$. Sen and co-authors found that the higher buffer on air supply in IFAS processes improve nitrification process and consequently reduce the $\mathrm{N}_{2} \mathrm{O}$ emissions during nitrification. Recently, Peng et al. (2016) in a model survey found that the gas production increases when the biofilm thickness increases. The first attempt to gain insight on how the peculiar features of IFAS - MBR systems influence the $\mathrm{N}_{2} \mathrm{O}$ emissions has been very recently presented by Mannina et al. (2017b). Mannina and co-workers investigated an IFAS-MBR system aimed at the biological nutrient removal and found a significant $\mathrm{N}_{2} \mathrm{O}$ production in the anaerobic and the anoxic reactors. This was mainly due to a twofold reason: $i$. The occurrence of the denitrifying PAOs activity under sporadic nitrite/nitrate presence inside the anaerobic reactor; ii. The combination of both heterotrophic non-PAOs and PAOs growth inside the anoxic reactors. However, the study of Mannina et al. (2017b) was performed at established operation conditions (e.g., indefinite sludge retention time). The SRT is an important operation operational variables which may influence $\mathrm{N}_{2} \mathrm{O}$ emissions. To what extend does the SRT influence the $\mathrm{N}_{2} \mathrm{O}$ from IFAS-MBR system has not yet assessed. Further, despite the results presented by Mannina et al. (2017b), knowledge on biofilm system is still immature (Todt and Dörsch, 2015). Therefore, the investigation of different operational conditions for a better understanding of the mechanisms involved in $\mathrm{N}_{2} \mathrm{O}$ production from hybrid systems aimed at nutrient removal is imperative.

In the light of the above discussion, the aim of the present study is to investigate the $\mathrm{N}_{2} \mathrm{O}$ production in an IFAS-MBR system for carbon and nutrients removal. To achieve such goals a University Cape Town (UCT) IFAS-MBR was monitored for 110 days and operated at different mixed liquor SRTs (namely, SRT $=\infty$, $\mathrm{SRT}=30 \mathrm{~d}$ and SRT $=15 \mathrm{~d}$ ). The pilot plant described in this paper is similar to the one presented by Mannina et al. (2017b) where only the SRT $=\infty$ was investigated. In this study the effect of the SRT was analysed assessing its short term effect with regards to the $\mathrm{N}_{2} \mathrm{O}$ emission.

\section{Materials and methods}

\subsection{Description of the UCT-IFAS-MBR pilot plant lay-out}

A UCT-IFAS-MBR pilot plant has been monitored during the experimental campaign (Fig. 1).

In details, the pilot plant consisted of anaerobic (volume $62 \mathrm{~L}$ ), anoxic (volume $102 \mathrm{~L}$ ) and aerobic (volume $211 \mathrm{~L}$ ) in-series compartments according to the UCT scheme (Ekama et al., 1983; Cosenza et al., 2013). The solid-liquid separation phase was achieved by means of an ultrafiltration hollow fibre membrane module (PURON ${ }^{\circledR}$ Triple bundle Demo Module, courtesy of Koch Membrane Systems Inc.). The membrane module (nominal pore size: $0.03 \mu \mathrm{m}$; membrane area: $1.4 \mathrm{~m}^{2}$ ) was placed inside a dedicated aerated compartment (MBR tank, volume $36 \mathrm{~L}$ ). An oxygen depletion reactor (ODR) allowed oxygen removal in the mixed liquor recycled from the MBR to the anoxic tank ( $\left.Q_{R A S}\right)$. The membrane was backwashed every $9 \mathrm{~min}$ for a period of $1 \mathrm{~min}$ by pumping a volume of permeate back ( $Q_{B W}$ represents the backwashing flow rate) from the Clean In Place (CIP) tank; an instantaneous permeate flux of $21 \mathrm{~L} \mathrm{~m}^{-2} \mathrm{~h}^{-1}$ was applied (QOUT,IST) valid only during the filtration time. The influent flow rate was set equal to $20 \mathrm{~L} \mathrm{~h}^{-1}\left(\mathrm{Q}_{\mathrm{IN}}\right)$. During pilot plant operation, a $20 \mathrm{~L} \mathrm{~h}^{-1}$ flow $\left(\mathrm{Q}_{\mathrm{R} 1}\right)$ was continuously pumped from the anoxic to the anaerobic tank. Furthermore, $100 \mathrm{~L} \mathrm{~h}^{-1}\left(\mathrm{Q}_{\mathrm{R} 2}\right)$ of mixed liquor were pumped from the aerobic to the MBR tank. A net permeate flow rate of $20 \mathrm{~L} \mathrm{~h}^{-1}$ was extracted (QouT) through the membrane. Therefore, the recycled activated sludge ( $\left.Q_{R A S}\right)$ from the MBR to the anoxic tank through the ODR tank was equal to $80 \mathrm{~L} \mathrm{~h}^{-1}$. The anaerobic, anoxic, aerobic and MBR

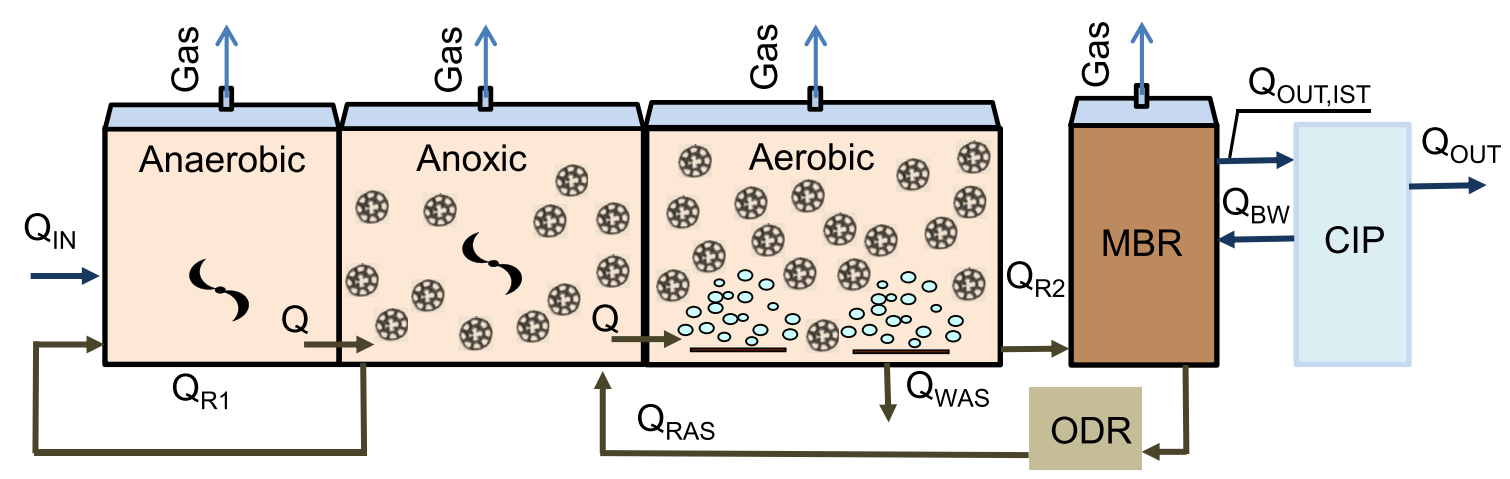

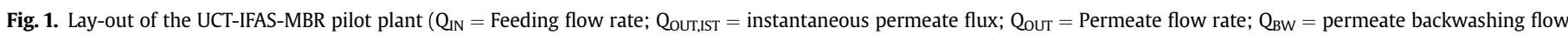

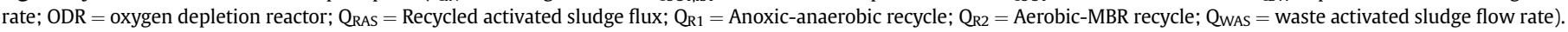


reactors were equipped with specific funnel shape covers that guaranteed gas accumulation in the headspace to capture the produced gas by sampling.

Furthermore, the anoxic and aerobic compartments were filled with suspended carriers (courtesy of Amitech Co. Ltd.) with a 15 and $40 \%$ filling ratio respectively, corresponding to a net surface area of almost $75 \mathrm{~m}^{2} \mathrm{~m}^{-3}$ and $205 \mathrm{~m}^{2} \mathrm{~m}^{-3}$, respectively. The filling ratios were chosen in agreement with literature data (Leyva-Díaz et al., 2016). The mixed liquor SRT was controlled by sludge withdrawals ( $\mathrm{Q}_{\text {WAS }}$ ) from the aerobic reactor.

In order to capture the overall off-gas emitted from the pilot plant, each reactor was equipped with a specific cover as described in Mannina et al. (2017a,b) (Fig. 1).

\subsection{Influent features and experimental phases}

The UCT-IFAS-MBR pilot plant was fed with real wastewater (collected at the University Campus) spiked by synthetic wastewater. The synthetic and real wastewater represented almost the 60 and $40 \%$ of the overall organic loading rate, respectively. More in details, the synthetic wastewater composition was: $30 \%$ of readily biodegradable COD (RBCOD) (dosed as sodium acetate) and 70\% of more slowly biodegradable (dosed as glycerol). It is worth noting that the real wastewater was collected at the University Campus and was characterized by high TN and ammonia content, due to the lack of kitchen food residues contribution.

Table 1 summarizes the average features of the influent wastewater as well as the operational conditions.

During the first 66 days, the pilot plant was operated with a complete sludge retention strategy, corresponding to indefinite SRT. From day 67 th to day 95th, regular sludge withdrawals were operated from the aerobic reactor in order to set the SRT at 30 days. Furthermore, from day 96th to day 115th the sludge withdrawals were increased as far as the corresponding SRT resulted equal to 15 days. Wasting sludge operations were carried out by means of a peristaltic pump that withdrew a constant sludge flow rate from the aerobic reactor (adjusted two times per week, after TSS measurements).

\subsection{Analytical procedures}

Samples collected from the influent wastewater, the mixed liquor inside the anaerobic, anoxic, aerobic and MBR tanks, and the effluent permeate were analysed for TSS, volatile suspended solids (VSS), total chemical oxygen demand ( $\left.\mathrm{COD}_{\mathrm{TOT}}\right)$, supernatant $\mathrm{COD}$ (CODsup), ammonium nitrogen $\left(\mathrm{NH}_{4}-\mathrm{N}\right)$, nitrite nitrogen $\left(\mathrm{NO}_{2}-\mathrm{N}\right)$, nitrate nitrogen $\left(\mathrm{NO}_{3}-\mathrm{N}\right)$, total nitrogen $(\mathrm{TN})$, phosphate $\left(\mathrm{PO}_{4}-\mathrm{P}\right)$, and total phosphorus (TP), Biochemical Oxygen Demand $\left(\mathrm{BOD}_{5}\right)$. All analyses were performed according to the Standard Methods

\section{Table 1}

Average features of the influent wastewater and operational conditions during the three experimental phases at MLSRT = indefinite, $30 \mathrm{~d}$ and $15 \mathrm{~d}$ respectively (in brackets the COD contribution of the synthetic wastewater).

\begin{tabular}{lllll}
\hline Parameter & Units & Phase I & Phase II & Phase III \\
\cline { 3 - 5 } & & Value & & \\
\hline COD & {$\left[\mathrm{mg} \mathrm{L}^{-1}\right]$} & $602(357)$ & $583(382)$ & $543(308)$ \\
Total nitrogen (TN) & {$\left[\mathrm{mg} \mathrm{L}^{-1}\right]$} & $55.46(0)$ & $76.91(0)$ & $105.00(0)$ \\
Total phosphorus (TP) & {$\left[\mathrm{mg} \mathrm{L}^{-1}\right]$} & $6.98(0)$ & $8.8(0)$ & $9.86(0)$ \\
Permeate Flux & {$\left[\mathrm{L} \mathrm{m}^{-2} \mathrm{~h}^{-1}\right]$} & 21 & 21 & 21 \\
Flow rate & {$\left[\mathrm{L} \mathrm{h}^{-1}\right]$} & 20 & 20 & 20 \\
SRT & {$[\mathrm{d}]$} & $\infty$ & 30 & 15 \\
HRT & {$[\mathrm{h}]$} & 20 & 20 & 20 \\
Duration & {$[\mathrm{d}]$} & $0-66$ & $67-95$ & $96-115$ \\
\hline
\end{tabular}

(APHA, 2005). Carriers from anoxic and aerobic reactors were periodically sampled in order to monitor the biofilm growth during experiments. The biofilm amount on the carriers was assessed according to procedure reported in Di Trapani et al. (2015).

Dissolved and gaseous $\mathrm{N}_{2} \mathrm{O}$ concentrations were also measured in each reactor and in the permeate by using a Gas Chromatograph (Thermo Scientific ${ }^{\mathrm{TM}}$ TRACE GC) equipped with an Electron Capture Detector (ECD). Furthermore, the $\mathrm{N}_{2} \mathrm{O}-\mathrm{N}$ fluxes $\left(\mathrm{gN}_{2} \mathrm{O}-\mathrm{N} \mathrm{m}^{-2} \mathrm{~h}^{-1}\right.$ ) from all reactors were quantified by measuring the gas flow rates, $\mathrm{Q}_{\mathrm{GAS}}\left(\mathrm{L} \mathrm{min}^{-1}\right)$. For further details on gas sampling and measurements, the reader is addressed to literature (APHA, 2005; Mannina et al., 2016b,c).

Moreover, with the aim to assess the $\mathrm{N}_{2} \mathrm{O}-\mathrm{N}$ production or consumption within each compartment, a nitrous oxide mass balance was calculated, according to Mannina et al. (2017b).

\section{Results and discussion}

\subsection{Pilot plant performances}

Table 2 summarizes the pilot plant removal performance. Data reported in Table 2 show that in terms of total COD removal efficiency ( $\left.\eta_{\text {TOT }}\right)$ the SRT variation did not exert any influence. Indeed, excellent $\eta_{\text {TOT }}$ removals were achieved over the entire experimental campaign. Conversely, the biological COD removal efficiency ( $\left.\eta_{\mathrm{BIO}}\right)$ was influenced by the decrease of the mixed liquor SRT. Indeed, with the decrease of the mixed liquor SRT from indefinite to 30 days an increase of the average $\eta_{\text {BIO }}$ value took place (from $76 \%$ to $80 \%$ ). This result can be likely due to the decrease of the reduced competition between the suspended biomass and the biofilm attached at lower mixed liquor SRT. However, $\eta_{\text {BIO }}$ decreased to $71 \%$ in Phase III, when the mixed liquor SRT was reduced to 15 days. Nevertheless, it has to be stressed that the temperature decrease from 18.2 to $15.3{ }^{\circ} \mathrm{C}$ (from Phase II through Phase III) could slightly affect biomass activity, thus contributing to the decrease of biological COD removal.

The total nitrogen removal efficiency ( $\eta \mathrm{N}_{\text {TOT }}$ ) decreased with the decreasing of the mixed liquor SRT (Table 2). In particular, the highest decrease of the $\eta \mathrm{N}_{\mathrm{TOT}}$ occurred when the mixed liquor SRT was reduced from 30 to 15 days despite the quite high nitrification efficiency $\left(\eta_{\text {nit }}\right)$ (Table 2$)$. Such a result could be related to the lower denitrification efficiency ( $\eta_{\text {denit }}$ ) at the lowest SRT, likely due to a sudden increase of the inlet nitrogen that promoted a decrease of the influent $\mathrm{C} / \mathrm{N}$ value.

In terms of phosphorus removal efficiency ( $\left.\eta_{\mathrm{PO} 4}\right)$ it was noticed a slight increase with the decrease of the SRT. Indeed, $\eta_{\mathrm{PO} 4}$ increased from $37 \%$ to $61 \%$ with the SRT decrease from indefinite to $15 \mathrm{~d}$. This result corroborates the findings of Ge et al. (2015), underlying a high competition between PAOs and ordinary heterotrophic organisms at high SRT. Fig. 2 depicts the trend profiles of TSS/VSS concentration as well as biofilm growth in the anoxic and aerobic compartments throughout experiments. The effect of the membrane and the internal tank recycles promoted the te TSS concentrations in the tanks towards the membrane, resulting in progressively increasing TSS from the anaerobic to the MBR tank (Ramphao et al., 2005). A general increase of the suspended biomass concentration was observed in the different compartments during Phase I, likely due to the absence of sludge withdrawals. In contrast, during Phase II it remained quite constant whilst in the Phase III a significant decrease was observed due to the increased sludge withdrawals. The attached biomass was quite low over the whole study - as expected at the prevailing conditions - with relatively high MLSS SRT in all phases resulting in more favourable conditions for the suspended biomass.

It is worth noting that Phase III was interrupted abruptly due to 
Table 2

Average values of removal efficiencies (in brackets the standard deviation values).

\begin{tabular}{|c|c|c|c|c|c|c|}
\hline SRT [d] & $\eta_{\text {тот }}[\%]$ & $\eta_{\text {BIO }}[\%]$ & $\eta \mathrm{N}_{\text {Tот }}[\%]$ & $\eta_{\text {nit }}[\%]$ & $\eta_{\text {denit }}[\%]$ & $\eta_{\mathrm{PO} 4}[\%]$ \\
\hline$\infty$ & $99( \pm 0.66)$ & $76( \pm 6.24)$ & $63( \pm 16.54)$ & $91( \pm 11.37)$ & $49( \pm 21.18)$ & $37( \pm 8.20)$ \\
\hline 30 & $99( \pm 0.36)$ & $80( \pm 3.72)$ & $61( \pm 18.96)$ & $91( \pm 10.68)$ & $50( \pm 24.02)$ & $53( \pm 4.61)$ \\
\hline 15 & $99( \pm 0.29)$ & $71( \pm 5.49)$ & $55( \pm 6.64)$ & $90( \pm 8.33)$ & $45( \pm 5.18)$ & $61( \pm 7.78)$ \\
\hline
\end{tabular}

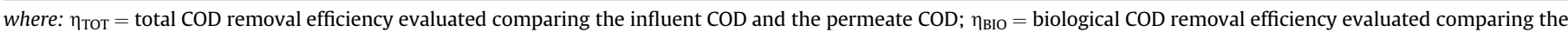

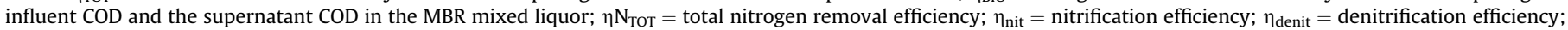
$\eta_{\mathrm{PO} 4}=\mathrm{PO}_{4}$-P removal efficiency. In brackets, the standard deviation is reported.
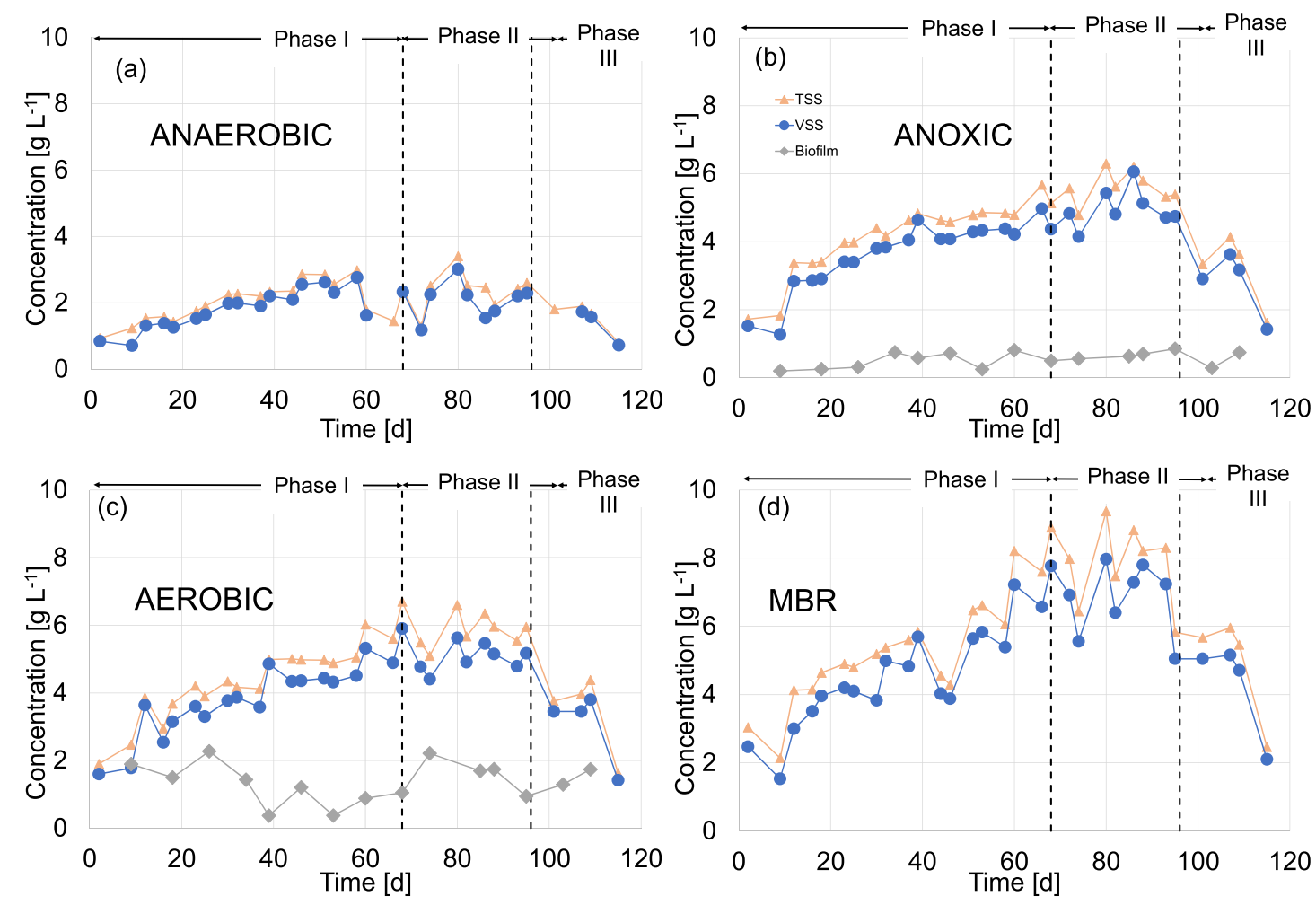

Fig. 2. Trend profiles of TSS, VSS and biofilm in the (a) anaerobic, (b) anoxic, (c) aerobic and (d) MBR compartments, respectively.

technical issues (including the lack of real wastewater feeding). Therefore, steady state conditions were not reached and future research activities must be carried out to deepen the system behaviour under these operational conditions.

\subsection{Dissolved and gaseous $\mathrm{N}_{2} \mathrm{O}$ concentration}

Fig. 3 reports the pattern of $\mathrm{N}_{2} \mathrm{O}-\mathrm{N}$ concentration in the gas and in the liquid samples withdrawn from each reactor and in the permeate, while Table 3 summarizes the average values of gaseous and dissolved $\mathrm{N}_{2} \mathrm{O}-\mathrm{N}$ concentrations throughout experiments.

Data reported in Fig. 3 show that the SRT variation strongly influenced the $\mathrm{N}_{2} \mathrm{O}-\mathrm{N}$ concentration both in gaseous and liquid samples. More precisely, by analysing data reported in Fig. 3a one can observe that, excepting some sporadic cases, the $\mathrm{N}_{2} \mathrm{O}-\mathrm{N}$ concentration in the gas samples increased with the decrease of the mixed liquor SRT. In details, the average $\mathrm{N}_{2} \mathrm{O}-\mathrm{N}$ concentrations in the Phase III (SRT = 15 days) was 4 times higher than that of Phase I (indefinite SRT). As an example, the average $\mathrm{N}_{2} \mathrm{O}-\mathrm{N}$ concentration in the gas samples withdrawn from the aerobic reactor was $10.83 \mu \mathrm{g} \mathrm{N}_{2} \mathrm{O}-\mathrm{N} \mathrm{L}^{-1}$ at SRT $=\infty$ and $23.69 \mu \mathrm{g} \mathrm{N}_{2} \mathrm{O}-\mathrm{N} \mathrm{L}^{-1}$ at SRT $=30 \mathrm{~d}$. Similarly, the average $\mathrm{N}_{2} \mathrm{O}-\mathrm{N}$ concentration in the gas samples withdrawn from the anaerobic reactor was $13.75 \mu \mathrm{g} \mathrm{N} \mathrm{N}_{2} \mathrm{O}-\mathrm{N}$
$\mathrm{L}^{-1}$ at SRT $=\infty$ and $47.38 \mu \mathrm{g} \mathrm{N} \mathrm{N}_{2} \mathrm{O}-\mathrm{N} \mathrm{L}^{-1}$ at SRT $=30 \mathrm{~d}$. Such result is in agreement with previous literature findings obtained for CAS systems (Kampschreur et al., 2009). Indeed, Zheng et al. (1994), when studying a continuous nitrifying CAS fed with artificial wastewater, highlighted that the $\mathrm{N}_{2} \mathrm{O}$ production increased when the SRT was decreased. Similarly, Noda et al. (2003) found that a SRT decrease promoted an increase of $\mathrm{N}_{2} \mathrm{O}$ production in a continuous activated sludge system fed with real wastewater.

Although the nitrification efficiency resulted high throughout experiments, the total nitrogen removal efficiency decreased with the decrease of SRT (see Table 2). This efficiency decrease might have caused nitrite accumulation in the system. Indeed, the mean nitrite concentration increased in the anoxic $\left(0.36 \mathrm{mg} \mathrm{NO} \mathrm{N}_{2}-\mathrm{N} \mathrm{L}^{-1}\right.$, $0.69 \mathrm{mg} \mathrm{NO} \mathrm{NO} \mathrm{L}_{2}-\mathrm{N}^{-1}$ and $1.62 \mathrm{mg} \mathrm{NO}_{2}-\mathrm{N} \mathrm{L}^{-1}$ ) as well in the aerobic reactor $\left(0.07 \mathrm{mg} \mathrm{NO}_{2}-\mathrm{N} \mathrm{L}^{-1}, 0.08 \mathrm{mg} \mathrm{NO}_{2}-\mathrm{N} \mathrm{L}^{-1}\right.$ and $0.82 \mathrm{mg} \mathrm{NO}_{2}-\mathrm{N}$ $\mathrm{L}^{-1}$ ) from SRT $=\infty$ to SRT $=30 \mathrm{~d}$ and SRT $=15 \mathrm{~d}$, respectively. Such circumstance is likely the main cause of the $\mathrm{N}_{2} \mathrm{O}$ production increase with the decrease of SRT. Furthermore, this observation is consistent with the findings of $\mathrm{Li}$ and $\mathrm{Wu}$ (2014) who identified in the higher concentration of $\mathrm{NO}_{2}-\mathrm{N}$ the main reason for the increased $\mathrm{N}_{2} \mathrm{O}$ emission at low SRTs. This aspect will be deepened in section 3.5 below.

The further SRT reduction (from $30 \mathrm{~d}$ to $15 \mathrm{~d}$ ) did not influence 
(a)

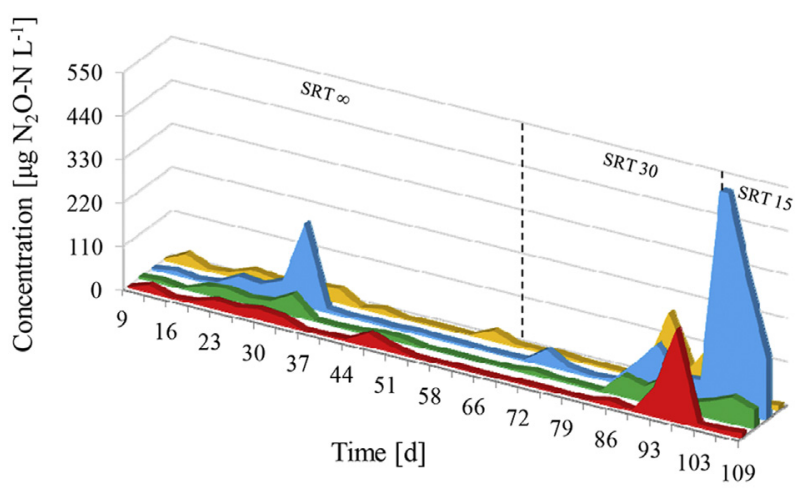

(b)

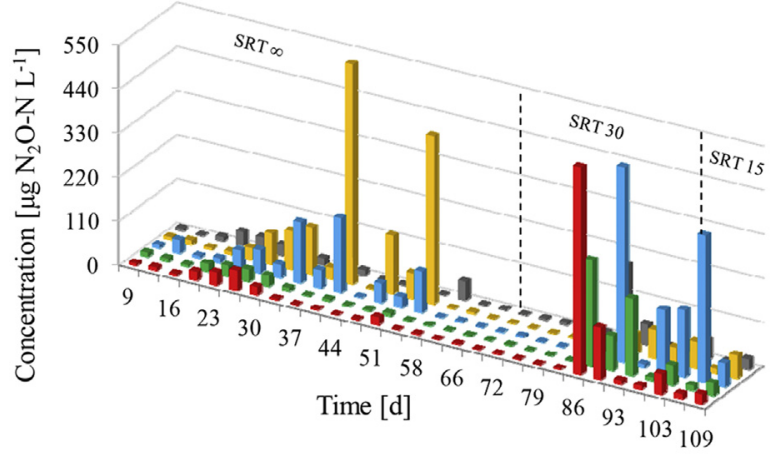

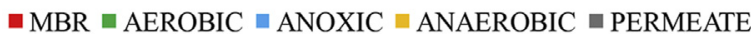

Fig. 3. Nitrous oxide concentration in the gaseous (a) and in liquid (b) samples for each SRT value.

Table 3

Average head-space and dissolved $\mathrm{N}_{2} \mathrm{O}-\mathrm{N}$ concentration for each reactor and experimental phase.

\begin{tabular}{llll}
\hline $\begin{array}{l}\mathrm{N}_{2} \mathrm{O}-\mathrm{N} \text { head space } \\
\text { concentration } \\
{\left[\mu \mathrm{g} \mathrm{N}_{2} \mathrm{O}-\mathrm{N} \mathrm{L}^{-1}\right]}\end{array}$ & Phase I & Phase II & Phase III \\
\hline Anaerobic & $13.75( \pm 12.73)$ & $47.38( \pm 66.02)$ & $50.62( \pm 70.14)$ \\
Anoxic & $22.84( \pm 50.54)$ & $40.32( \pm 39.49)$ & $377.22( \pm 230.58)$ \\
Aerobic & $10.83( \pm 14.26)$ & $23.69( \pm 26.54)$ & $51.79( \pm 11.93)$ \\
$\mathrm{MBR}$ & $9.79( \pm 10.69)$ & $36.17( \pm 77.50)$ & $8.93( \pm 2.90)$ \\
\hline $\mathrm{N}_{2} \mathrm{O}-\mathrm{N}$ dissolved & Phase I & Phase II & Phase III \\
$\quad$ concentration & & & \\
$\quad\left[\mu \mathrm{N} \mathrm{N}_{2} \mathrm{O}-\mathrm{N} \mathrm{L}{ }^{-1}\right]$ & & & \\
\hline Anaerobic & $102.33( \pm 189.57)$ & $19.56( \pm 26.79)$ & $45.61( \pm 29.67)$ \\
Anoxic & $44.85( \pm 54.38)$ & $75.45( \pm 162.48)$ & $197.79( \pm 155.64)$ \\
Aerobic & $9.76( \pm 10.18)$ & $62.09( \pm 99.97)$ & $31.94( \pm 19.02)$ \\
MBR & $10.39( \pm 13.96)$ & $75.02( \pm 171.47)$ & $30.18( \pm 18.99)$ \\
Permeate flux & $14.22( \pm 14.99)$ & $31.97( \pm 60.44)$ & $28.39( \pm 19.59)$ \\
\hline
\end{tabular}

In brackets the standard deviation is reported.

the average $\mathrm{N}_{2} \mathrm{O}-\mathrm{N}$ gas concentration, excepting the MBR reactor. Indeed, the average $\mathrm{N}_{2} \mathrm{O}-\mathrm{N}$ gaseous concentration in the MBR tank decreased from $37.17 \mu \mathrm{g} \mathrm{N} \mathrm{N}_{2} \mathrm{O}-\mathrm{N} \mathrm{L}^{-1}$ to $8.93 \mu \mathrm{g} \mathrm{N}_{2} \mathrm{O}-\mathrm{N} \mathrm{L}^{-1}$ when the mixed liquor SRT was reduced from 30 to $15 \mathrm{~d}$. These results are consistent with previous studies (Mannina et al., 2017b) confirming the key role played by the SRT, for the MBR tank, in the reduction $\mathrm{N}_{2} \mathrm{O}-\mathrm{N}$ gaseous concentration.

A similar trend was also obtained for the $\mathrm{N}_{2} \mathrm{O}-\mathrm{N}$ concentration dissolved in the liquid phase only in the anoxic reactor (Fig. $3 \mathrm{~b}$ ). More precisely, in the anoxic reactor the dissolved $\mathrm{N}_{2} \mathrm{O}-\mathrm{N}$ concentrations increased with the decrease of mixed liquor SRT, thus suggesting that under low SRT values there is a predominant production of $\mathrm{N}_{2} \mathrm{O}-\mathrm{N}$ inside the anoxic tank (Mannina et al., 2016c). As an example, the average $\mathrm{N}_{2} \mathrm{O}-\mathrm{N}$ concentration dissolved in the liquid phase into the anoxic reactor increased from $75.45 \mu \mathrm{g} \mathrm{N}_{2} \mathrm{O}-\mathrm{N}$ $\mathrm{L}^{-1}$ to $197.79 \mu \mathrm{g} \mathrm{N} \mathrm{N}_{2}-\mathrm{N} \mathrm{L}^{-1}$ with the decrease of the mixed liquor SRT from 30 to $15 \mathrm{~d}$. This result is likely due to a twofold reason: $\mathrm{i}$ : the activity of suspended biomass increased due to the decrease of SRT thanks to a sort of "renewal" effect; ii: the specific biofilm contribution. Indeed, regarding this latter aspect the biofilm concentration showed fluctuations during the entire experimental duration with biofilm concentrations down to 0.4 and $0.2 \mathrm{~g} \mathrm{TS} \mathrm{L}^{-1}$ in the aerobic and anoxic compartment, respectively. This behaviour likely influenced the amount of $\mathrm{N}_{2} \mathrm{O}-\mathrm{N}$ concentration inside the anoxic and aerobic tank due to the variation of the biofilm contribution during the nitrification and denitrification processes. Indeed, during Phase I (SRT $=\infty \mathrm{d}$ ) a slight increase of biofilm concentration in both aerobic and anoxic reactors occurred, likely due to the simultaneous decrease of the suspended biomass (due to the increased sludge withdrawals). Indeed, the decrease of the suspended biomass could have reduced the competition between the two biomasses for the availability of the substrates, thus enhancing the growth of the biofilm. The increase of biofilm concentration could positively affect nitrification during Phase III, thus keeping the $\mathrm{N}_{2} \mathrm{O}-\mathrm{N}$ concentration both in gaseous and liquid samples of the aerobic reactor almost equal to what observed in the previous Phase II. When the SRT was reduced to 30 days a substantial decrease of the dissolved $\mathrm{N}_{2} \mathrm{O}$ concentration occurred inside the anaerobic reactor. Indeed, the average dissolved $\mathrm{N}_{2} \mathrm{O}$ concentration was equal to 102.33 and $19.56 \mu \mathrm{g} \mathrm{N} \mathrm{N}_{2} \mathrm{O}-\mathrm{N} \mathrm{L}^{-1}$ for Phase I and Phase II, respectively. Such a result is likely debited to a reduced activity of PAOs as denitrifiers with the reduction of SRT.

It is worth noting that during the first 15 days of Phase II (SRT $=30 \mathrm{~d}$ ) no significant variation in $\mathrm{N}_{2} \mathrm{O}-\mathrm{N}$ concentration (both dissolved and gaseous) occurred (Fig. 3). Such circumstance is likely due to a time lag necessary to the biological system to cope with the new SRT value.

Furthermore, it was observed that the $\mathrm{N}_{2} \mathrm{O}$ concentration measured in the permeate flow rate was not negligible, in contrast to what highlighted in previous studies (Guo et al., 2012). In detail, the average $\mathrm{N}_{2} \mathrm{O}-\mathrm{N}$ concentration in the permeate samples ranged between $14.21 \mu \mathrm{g} \mathrm{N}_{2} \mathrm{O}-\mathrm{N} \mathrm{L}^{-1}$ and $31.97 \mu \mathrm{g} \mathrm{N} \mathrm{N}_{2} \mathrm{O}-\mathrm{N} \mathrm{L}^{-1}$ at SRT $=\infty$ and $30 \mathrm{~d}$, respectively, thus demonstrating that the $\mathrm{N}_{2} \mathrm{O}-\mathrm{N}$ concentration in the permeate was not negligible to what measured in the other reactors. Therefore, the amount of $\mathrm{N}_{2} \mathrm{O}$ discharged with the permeate in the receiving water body could represent a serious threat to the environment.

\section{3. $\mathrm{N}_{2} \mathrm{O}$ fluxes}

Fig. 4 shows the pattern of $\mathrm{N}_{2} \mathrm{O}-\mathrm{N}$ fluxes assessed in both not aerated (a) and aerated (b) reactors, whilst Table 4 reports a summary of the average $\mathrm{N}_{2} \mathrm{O}-\mathrm{N}$ fluxes for each reactor in the different Phases.

Data reported in Fig. 4 b show that the $\mathrm{N}_{2} \mathrm{O}-\mathrm{N}$ flux of the aerated reactors (aerobic and MBR) is almost 2 order of magnitude higher than that of the non-aerated reactors (anaerobic and anoxic) (Fig. 4a). This result was much more evident at the end of Phase II $(\mathrm{SRT}=30 \mathrm{~d})$ and throughout Phase III (SRT $=15 \mathrm{~d}$ ) due to the increase of $\mathrm{N}_{2} \mathrm{O}-\mathrm{N}$ concentration in the gaseous samples. Despite similar results were also obtained in Mannina et al. (2017b), here the decrease of SRT emphasizes the role of aerated reactors in terms of $\mathrm{N}_{2} \mathrm{O}-\mathrm{N}$ flux emissions.

Significant fluxes of nitrous oxide were observed from the MBR. Due to the short hydraulic retention time (HRT) (almost $20 \mathrm{~min}$ ), it is reasonable to assume that no biological process could occur inside the MBR tank. Although some biological processes could occur also with a so short HRT, $\mathrm{N}_{2} \mathrm{O}$ fluxes up to $400 \mathrm{mg} \mathrm{N}_{2} \mathrm{O}-\mathrm{N} \mathrm{m}^{-2} \mathrm{~h}^{-1}$ in 
(a)
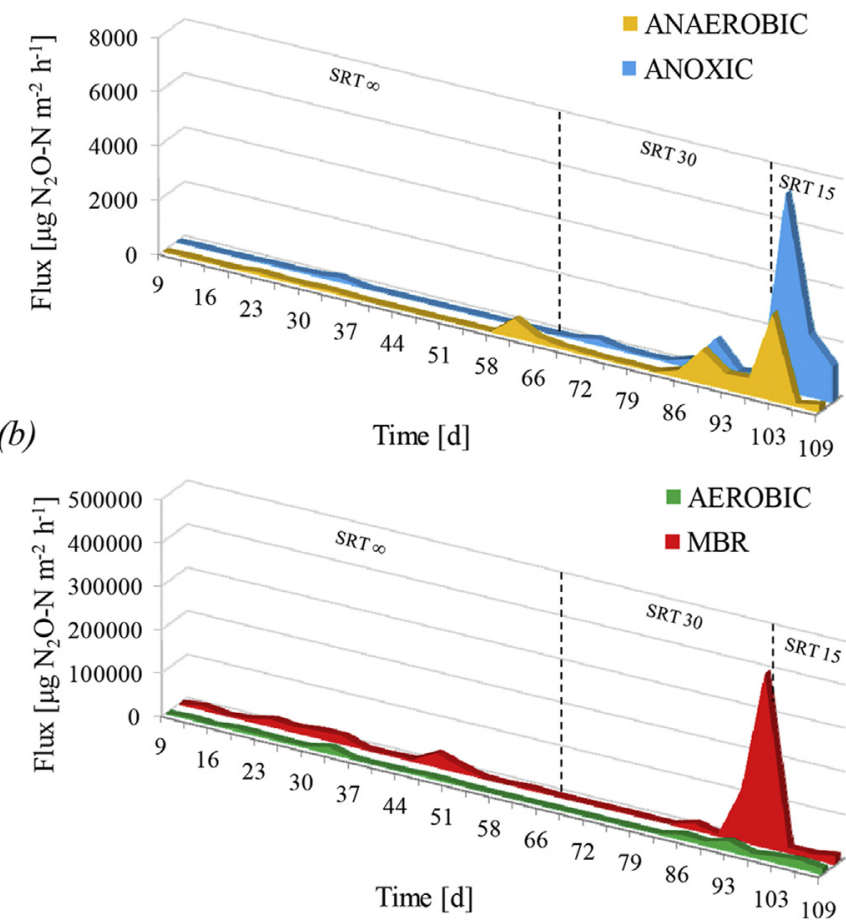

Fig. 4. $\mathrm{N}_{2} \mathrm{O}-\mathrm{N}$ flux in anaerobic and anoxic reactors (a) and in aerobic and MBR reactors (b).

Table 4

Average $\mathrm{N}_{2} \mathrm{O}-\mathrm{N}$ flux for each reactor and experimental phase.

\begin{tabular}{|c|c|c|c|}
\hline $\begin{array}{l}\mathrm{N}_{2} \mathrm{O}-\mathrm{N} \text { flux } \\
{\left[\mu \mathrm{g} \mathrm{N}_{2} \mathrm{O}-\mathrm{N} \mathrm{m} \mathrm{m}^{-2} \mathrm{~h}^{-1}\right]}\end{array}$ & Phase I & Phase II & Phase III \\
\hline Anaerobic & $72( \pm 165)$ & $325( \pm 415)$ & $1193( \pm 1740)$ \\
\hline Anoxic & $22( \pm 38)$ & $308( \pm 392)$ & $3631( \pm 3205)$ \\
\hline Aerobic & $2396( \pm 3544)$ & $5990( \pm 7786)$ & $15352( \pm 3038)$ \\
\hline MBR & $7797( \pm 9016)$ & $60156( \pm 133336)$ & $14336( \pm 4667)$ \\
\hline
\end{tabular}

In brackets the standard deviation is reported.

the MBR reactor were likely produced somewhere else. It is reasonable that this huge emission might be due to the dissolved $\mathrm{N}_{2} \mathrm{O}$ concentration coming from the $\mathrm{Q}_{\mathrm{R} 2}$ flow rate and that it stripped out in the MBR tank, thus contributing to the emission.

\subsection{Emission factors}

Fig. 5 shows the trend of the emission factor of each reactor. In particular, data reported in Fig. 4 show that a quite constant emission factor occurred during the entire experimental campaign, from each reactor, excepting the last days of Phase II (SRT $=30 \mathrm{~d}$ ).

This result is mainly due to the increased air supply in the aerated reactors in the last portion of Phase II, aimed at assessing the effect of the air flow rate on both membrane fouling and $\mathrm{N}_{2} \mathrm{O}$ stripping. Therefore, the $\mathrm{N}_{2} \mathrm{O}-\mathrm{N}$ emission factor assessed during days 93 rd and 95th increased considerably up to the 38 and $35 \%$ of the total influent nitrogen, respectively. On average, excluding data of days $93 \mathrm{rd}$ and 95 th the average $\mathrm{N}_{2} \mathrm{O}-\mathrm{N}$ emission factor was equal to $0.13 \%, 0.21 \%$ and $0.76 \%$ of the total influent nitrogen for SRT $=\infty$, $\mathrm{SRT}=30 \mathrm{~d}$ and SRT $=15 \mathrm{~d}$ respectively, thus demonstrating a slight increase of the $\mathrm{N}_{2} \mathrm{O}-\mathrm{N}$ emission factor with the decrease of the mixed liquor SRT. Such result is likely due to a limitation exerted by the low SRT to the whole nitrogen removal process. Indeed, as

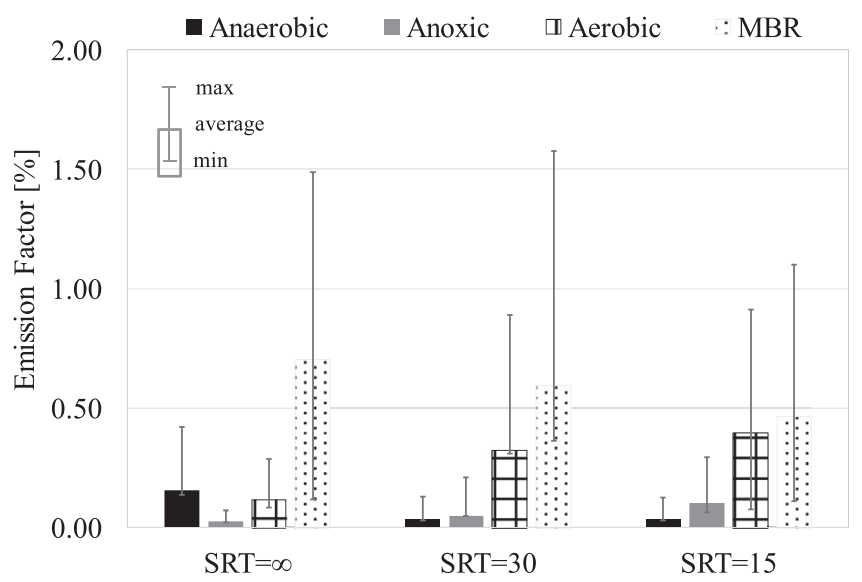

Fig. 5. $\mathrm{N}_{2} \mathrm{O}-\mathrm{N}$ emission factor pattern during experimentation during $\mathrm{SRT}=\infty$ $\mathrm{SRT}=30 \mathrm{~d}$ and SRT $=15 \mathrm{~d}$.

reported in Table 2 slight decrease of TN removal efficiency occurred with the SRT decrease. Therefore, the observed results suggest to operate the pilot plant with higher SRT values in view to reduce the $\mathrm{N}_{2} \mathrm{O}-\mathrm{N}$ emissions.

The achieved results are in agreement with previous studies that quantified the $\mathrm{N}_{2} \mathrm{O}$ emission from WWTPs. Foley and Lant (2007) derived from 11 full-scale and lab-scale wastewater systems with biological nutrient removal (BNR) a median emission factor of $0.01 \mathrm{kgN}_{2} \mathrm{O}-\mathrm{N} \mathrm{kg}^{-1} \mathrm{~N}_{\text {influent }}$ ( $1 \%$ of the influent total nitrogen). Foley et al. (2010) found a high variability of the $\mathrm{N}_{2} \mathrm{O}-\mathrm{N}$ emission factor ranging between 0.006 and $0.253 \mathrm{kgN}_{2} \mathrm{O}-\mathrm{N} \mathrm{kg}^{-1} \mathrm{~N}$ denitrified (average: $0.035 \pm 0.027$ ). However, the emission factors obtained here are lower than that obtained for CAS by Foley and Lant (2007) even during Phase III when the maximum emission factor value $(0.76 \%$ of the total influent nitrogen) was achieved. Such a result is likely due to the positive effect obtained here by the biofilm role during the nitrogen transformation processes. However, no comprehensive comparison between Phases I and II can be performed due to the aeration increase in the last days of Phase II.

\subsection{Influence of nitrite accumulation on $\mathrm{N}_{2} \mathrm{O}-\mathrm{N}$ production}

The influence exerted by the nitrogen forms on the $\mathrm{N}_{2} \mathrm{O}-\mathrm{N}$ emission was also investigated in the present study. In Fig. 6, the correlation between the $\mathrm{NO}_{2}-\mathrm{N}$ concentration in the aerobic (Fig. 6a) and in the anoxic (Fig. 6b) reactor with the gaseous $\mathrm{N}_{2} \mathrm{O}-\mathrm{N}$ concentration in the anoxic reactor is reported.

From the observation of data reported in Fig. 6, it is worth noting a positive linear correlation between the $\mathrm{N}_{2} \mathrm{O}-\mathrm{N}$ concentration in the gas sample of the anoxic tank and the $\mathrm{NO}_{2}-\mathrm{N}$ concentrations in the aerobic (Fig. 6a) as well as anoxic reactor (Fig. 6b). This result confirms that incomplete nitrification and denitrification, highlighted by the $\mathrm{NO}_{2}-\mathrm{N}$ accumulation in the mixed liquor of the aerobic and anoxic tank reactors, might promote the increase of the $\mathrm{N}_{2} \mathrm{O}-\mathrm{N}$ production.

Nitrite accumulation in the anoxic reactor (Fig. 6b), up to $3 \mathrm{mg}$ $\mathrm{NO}_{2}-\mathrm{N} \mathrm{L}^{-1}$, demonstrates that the denitrification could be likely limited by the decrease of SRT. Furthermore, the high correlation $\left(\mathrm{R}^{2}=0.84\right)$ existing between $\mathrm{N}_{2} \mathrm{O}-\mathrm{N}$ concentration and nitrite dissolved concentration in the anoxic reactor suggests that the incomplete denitrification was the main source of $\mathrm{N}_{2} \mathrm{O}$ production. Indeed, the anoxic reactor contribution to the total $\mathrm{N}_{2} \mathrm{O}$ emission increased during experiments from $2.46 \%$ to $4.97 \%$ and to $10.07 \%$ in Phase I $($ SRT $=\infty)$, Phase II $($ SRT $=30 \mathrm{~d})$ and Phase III $($ SRT $=15 \mathrm{~d})$, respectively. 

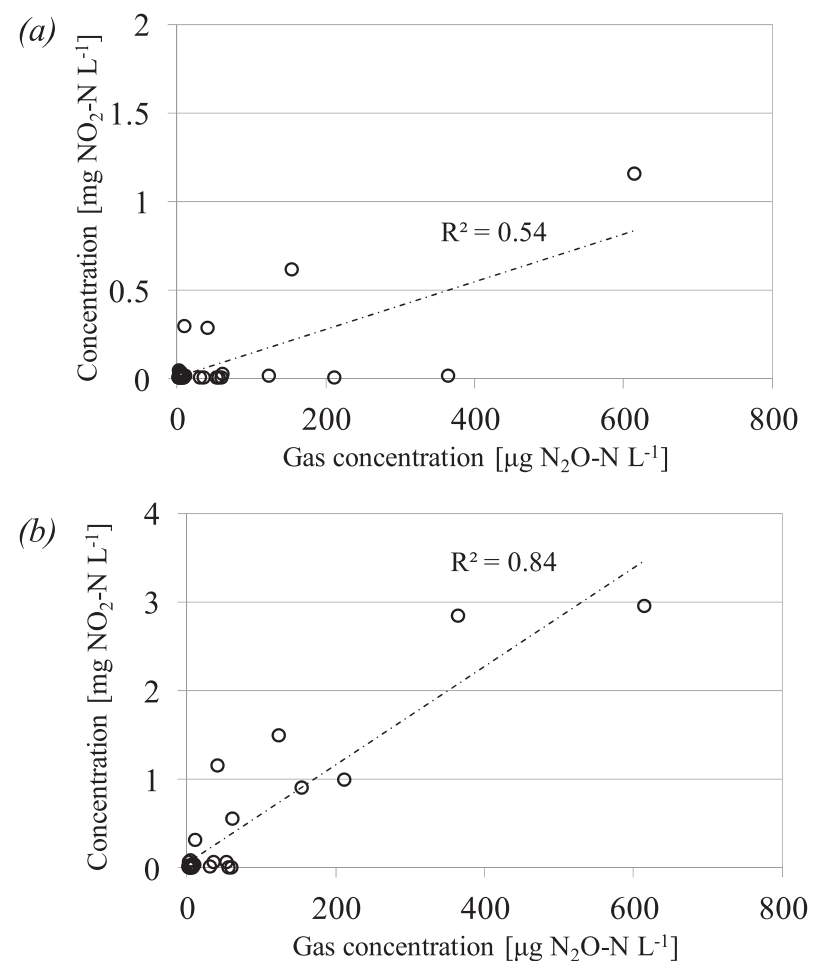

Fig. 6. Correlation between $\mathrm{N}_{2} \mathrm{O}-\mathrm{N}$ concentration in the gas samples of anoxic reactor and nitrite dissolved concentration in the aerobic reactor (a) and anoxic reactor (b).
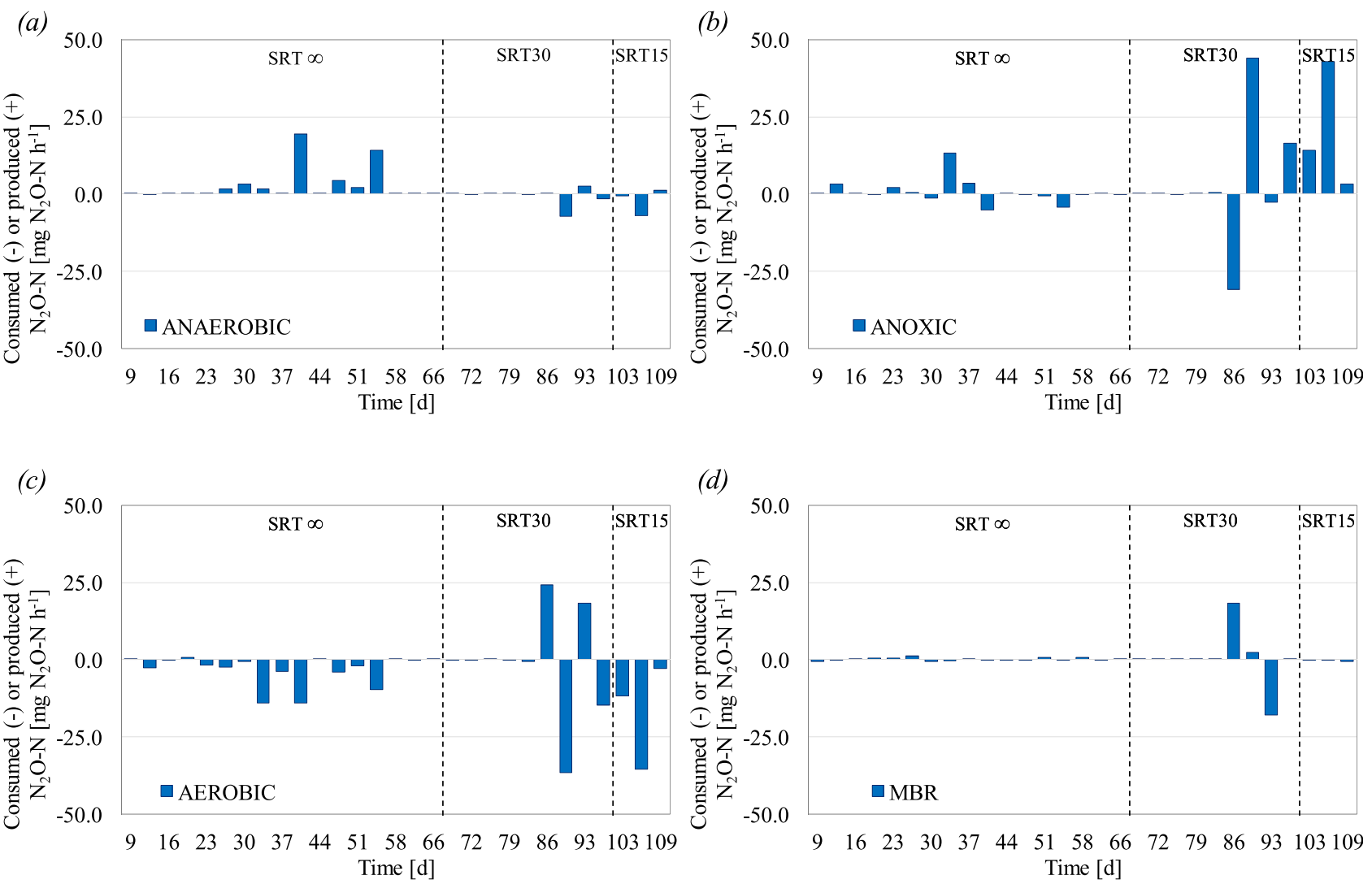

Fig. 7. $\mathrm{N}_{2} \mathrm{O}-\mathrm{N}$ mass balance for anaerobic (a), anoxic (b), aerobic (c) and MBR reactors (d). 
consumer. Such observation can be likely due to a twofold reason: i) oxidation of dissolved nitrous oxide arriving from the anoxic; ii) stripping out of nitrous oxide coming from the anoxic and also eventually produced inside the aerobic (autotrophic denitrification). In contrast, the anoxic tank was on average a nitrous oxide producer and, as above discussed, such production increased with the SRT decrease. Such observation outlines that the main $\mathrm{N}_{2} \mathrm{O}$ production pathway resulted the incomplete denitrification, confirmed also by the nitrite accumulation previously discussed.

However, it is difficult to point out a clear explanation for the differences that occurred in each reactor during the experimentation. Several reason could indeed affect the $\mathrm{N}_{2} \mathrm{O}$ mass balance. Indeed in each reactor different process take place. Furthermore, each reactor is featured by different mass fluxes (that affect the mass balance). Moreover, the processes occurring in a single reactor can be transferred in the following compartments, thus affecting significantly the behaviour of the whole pilot plant.

\section{Conclusions}

In the present study, the influence of the mixed liquor SRT on the $\mathrm{N}_{2} \mathrm{O}$ formation in a UCT-IFAS-MBR pilot plant was explored. In general, results showed that the SRT decrease promoted an increase of $\mathrm{N}_{2} \mathrm{O}-\mathrm{N}$ concentration (both in gaseous and liquid samples) and emission. The highest $\mathrm{N}_{2} \mathrm{O}-\mathrm{N}$ concentration was found in the off-gas of the anoxic reactor during Phase III (377.22 $\left.\mu \mathrm{g} \mathrm{N}_{2} \mathrm{O}-\mathrm{N} \mathrm{L}^{-1}\right)$. In contrast, the highest emitted $\mathrm{N}_{2} \mathrm{O}$ flux was achieved in the MBR tank (up to $1430 \mathrm{mg} \mathrm{N} \mathrm{N}_{2} \mathrm{O}-\mathrm{N} \mathrm{m}^{-2} \mathrm{~h}^{-1}$ ) reducing the SRT from indefinite to $30 \mathrm{~d}$. This result is likely related to the high aeration provided in the MBR for fouling mitigation that might have promoted the stripping of the $\mathrm{N}_{2} \mathrm{O}-\mathrm{N}$ dissolved in the liquid phase. The increase of biofilm concentration has likely positively contributed to the nitrification even at low SRT value. Indeed, the $\mathrm{N}_{2} \mathrm{O}-\mathrm{N}$ concentration both in gaseous and liquid samples of the aerobic reactor during the phase at SRT equal to $15 \mathrm{~d}$ was almost equal to what observed at SRT equal to $30 \mathrm{~d}$.

The emission factor highlighted a slight increase with the decrease of the SRT $(0.13 \%, 0.21 \%$ and $0.76 \%$ of influent nitrogen in Phase I, Phase II and Phase III, respectively). Such result was likely due to the limitation of nitrification and denitrification processes with the decrease of the SRT, that likely caused a slight $\mathrm{NO}_{2}-\mathrm{N}$ accumulation thus promoting the nitrous oxide production. Therefore, the SRT was confirmed to be a key parameter with regards to, on one hand, the nitrous oxide formation and emission while, on the other hand, the system removal efficiency. Globally, high SRT values (higher than $30 \mathrm{~d}$ ) are suggested to mitigate the $\mathrm{N}_{2} \mathrm{O}-\mathrm{N}$ emissions and improve the nitrogen removal. However, the effect of the adopted SRT on the phosphorus removal has to be analysed, since low SRT values are more advisable to remove phosphorus.

\section{Acknowledgements}

This work forms part of a research project supported by grant of the Italian Ministry of Education, University and Research (MIUR) through the Research project of national interest PRIN2012 (D.M. 28 dicembre 2012 n. 957/Ric - Prot. 2012PTZAMC) entitled “Energy consumption and GreenHouse Gas (GHG) emissions in the wastewater treatment plants: a decision support system for planning and management - http://ghgfromwwtp.unipa.it" in which the first author of this paper is the Principal Investigator.

Finally, authors warmly thank Prof. Emeritus Hallvard Ødegaard, for his precious contribution and support in reviewing the manuscript.

\section{References}

APHA, 2005. Standard Methods for the Examination of Water and Wastewater APHA, AWWA and WPCF, Washington DC, USA.

Chandran, K., Stein, L.Y., Klotz, M.G., van Loosdrecht, M.C.M., 2011. Nitrous oxide production by lithotrophic ammonia oxidizing bacteria and implications for engineered nitrogen-removal systems. Biochem. Soc. Trans. 39, 1832-1837.

Chiu, Y.C., Chung, M.S., 2000. BNP test to evaluate the influence of $\mathrm{C} / \mathrm{N}$ ratio on $\mathrm{N}_{2} \mathrm{O}$ production in biological denitrification. Water Sci. Technol. 42, 23-27.

Cosenza, A., Di Bella, G., Mannina, G., Torregrossa, M., Viviani, G., 2013. Biological nutrient removal and fouling phenomena in a university of cape town membrane bioreactor treating high nitrogen loads. J. Environ. Eng. 139, 773-780.

Di Trapani, D., Di Bella, G., Mannina, G., Torregrossa, M., Viviani, G., 2014. Comparison between moving bed-membrane bioreactor (MB-MBR) and membrane bioreactor (MBR) systems: influence of wastewater salinity variation. Bioresour. Technol. 162, 60-69.

Di Trapani, D., Di Bella, G., Mannina, G., Torregrossa, M., Viviani, G., 2015. Effect of C $\mathrm{N}$ shock variation on the performances of a moving bed membrane bioreactor. Bioresour. Technol. 189, 250-257.

Ekama, G.A., Siebritz, I.P., Marais, G.R., 1983. Considerations in the process design of nutrient removal activated sludge processes. Water Sci. Technol. 15 (3-4), $283-318$.

Foley, J., de Haas, D., Yuan, Z., Lant, P., 2010. Nitrous oxide generation in full-scale biological nutrient removal wastewater treatment plants. Water Res. 44 831-844.

Foley, J., Lant, P., 2007. Fugitive Greenhouse Gas Emissions from Wastewater Systems. http://espace.uq.edu.au/view/UQ:139104.

Ge, H., Batstone, D.J., Keller, J., 2015. Biological phosphorus removal from abattoir wastewater at very short sludge ages mediated by novel PAO clade comamonadaceae. Water Res. 69, 173-182.

Guo, L., Porro, J., Sharma, K.R., Amerlinck, Y., Benedetti, L., Nopens, I., Shaw, A., Van Hulle, S.W.H., Yuan, Z., Vanrolleghem, P.A., 2012. Towards a benchmarking tool for minimizing wastewater utility greenhouse gas footprints. Water Sci. Technol. 66 (11), 2483-2495.

IPCC, 2007. Changes in atmospheric constituents and in radiative forcing. In: Solomon, S., et al. (Eds.), Climate Change 2007: the Physical Science Basis. Contribution of Working Group I to the Fourth Assessment Report of the Intergovernmental Panel on Climate Change. Cambridge University Press, Cambridge, pp. 114-143.

Kampschreur, M.J., Temmink, H., Kleerebezem, R., Jetten, M.S.M., van Loosdrecht, M.C.M., 2009. Nitrous oxide emission during wastewater treatment Water Res. 43, 4093-4103.

Law, Y., Ni, B.J., Lant, P., Yuan, Z., 2012. $\mathrm{N}_{2} \mathrm{O}$ production rate of an enriched ammonia-oxidising bacteria culture exponentially correlates to its ammonia oxidation rate. Water Res. 46, 3409-3419.

Li, B., Wu, G., 2014. Effects of sludge retention times on nutrient removal and nitrous oxide emission in biological nutrient removal processes. Int. J. Environ. Res. Public Health 11, 3553-3569. http://dx.doi.org/10.3390/ijerph110403553.

Leyva-Díaz, J.C., Muñío, M.M., González-LópezMartín-Pascual, J., Poyatos, J.M., 2016. Anaerobic/anoxic/oxic configuration in hybrid moving bed biofilm reactormembrane bioreactor for nutrient removal from municipal to treat wastewater. Ecol. Eng. 91, 449-458. http://dx.doi.org/10.1007/s13762-016-1169-y. Int. J. Environ, Sci. Technol., 1-30.

Liu, Y., Peng, L., Chen, X., Ni, B.-J., 2015. Mathematical modeling of nitrous oxide production during denitrifying phosphorus removal process. Environ. Sci. Technol. 49, 8595-8601.

Mannina, G., Ekama, G., Caniani, D., Cosenza, A., Esposito, G., Gori, R., GarridoBaserba, M., Rosso, D., Olsson, G., 2016a. Greenhouse gases from wastewater treatment - a review of modelling tools. Sci. Total Environ. 551-552, 254-270.

Mannina, G., Morici, C., Cosenza, A., Di Trapani, D., Ødegaard, H., 2016b. Greenhouse gases from sequential batch membrane bioreactor: a pilot plant case study. Biochem. Eng. J. 112, 114-122.

Mannina, G., Cosenza, A., Di Trapani, D., Laudicina, V.A., Morici, C., Ødegaard, H. 2016c. Nitrous oxide emissions in a membrane bioreactor treating saline wastewater contaminated by hydrocarbons. Bioresour. Technol. 219, 289-297. http://dx.doi.org/10.1016/j.biortech.2016.07.124.

Mannina, G., Capodici, M., Cosenza, A., Di Trapani, D., van Loosdrecht, M., 2017a. Nitrous oxide emission in a University of Cape Town membrane bioreactor: the effect of carbon to nitrogen ratio. J. Clean. Prod. 149, 180-190.

Mannina, G., Capodici, M., Cosenza, A., Di Trapani, D., Laudicina, V.A., Ødegaard, H. 2017b. Nitrous oxide from moving bed based integrated fixed film activated sludge membrane bioreactors. J. Environ. Manag. 187, 96-102.

Ni, B., Yuan, Z., 2015. Recent advances in mathematical modeling of nitrous oxides emissions from wastewater treatment processes. Water Res. 87, 336-346.

Noda, N., Kaneko, N., Mikami, M., Kimochi, Y., Tsuneda, S., Hirata, A., Mizuochi, M., Inamori, Y., 2003. Effects of SRT and DO on $\mathrm{N}_{2} \mathrm{O}$ reductase activity in an anoxicoxic activated sludge system. Water Sci. Technol. 48 (11-12), 363-370.

Park, K.Y., Inamori, Y., Mizuochi, M., Ahn, K.H., 2000. Emission and control of nitrous oxide from a biological wastewater treatment system with intermittent aeration. J. Biosci. Bioeng. 90, 247-252.

Paudel, S.R., Choi, O., Khanal, S.K., Chandran, K., Kim, S., Lee, J.W., 2015. Effects of temperature on nitrous oxide $\left(\mathrm{N}_{2} \mathrm{O}\right)$ emission from intensive aquaculture system. Sci. Total Environ. 518-519, 16-23.

Peng, L., Liu, Y., Ni, B., 2016. Nitrous oxide production in completely autotrophic 
nitrogen removal biofilm process: a simulation study. Chem. Eng. J. 287 217-224.

Peng, L.B.-J., Ni Ye, L., Yuan, Z., 2015. The combined effect of dissolved oxygen and nitrite on $\mathrm{N}_{2} \mathrm{O}$ production by ammonia oxidizing bacteria in an enriched nitrifying sludge. Water Res. 73, 29-36.

Ramphao, M., Wentzel, M.C., Merritt, R., Ekama, G.A., Young, T., Buckley, C.A., 2005. Impact of membrane solid-liquid separation on design of biological nutrient removal activated sludge systems. Biotechnol. Bioeng. 89, 630-646.

Sen, D., Lodhi, A., Copithorn, R., Randall, C.W., Pehrson, R., Chandran, K., 2010. Differences in GHG emission between IFAS and activated sludge - developing a fast and accurate computational model - AQUIFAS + - to simulate media, mixing and aeration, design and operation of plants. In: WEF/IWA Biofilm Reactor Technology Conference, vol. 2010.

Stenström, F., Tjus, K., la Cour Jansen, J., 2014. Oxygen-induced dynamics of nitrous oxide in water and off-gas during the treatment of digester supernatant. Wate
Sci. Technol. 69.1, 84-91.

Tallec, G., Garnier, J., Billen, G., Gousailles, M., 2008. Nitrous oxide emissions from denitrifying activated sludge of urban wastewater treatment plants, under anoxia and low oxygenation. Bioresour. Technol. 99, 2200-2209.

Todt, D., Dörsch, P., 2015. Nitrous oxide emissions in a biofilm loaded with different mixtures of concentrated household wastewater. Int. J. Environ. Sci. Technol. 12 (11), 3405-3416.

Zeng, R.J., Yuan, Z.G., Keller, J., 2003. Enrichment of denitrifying glycogenaccumulating organisms in anaerobic/anoxic activated sludge system. Biotechnol. Bioeng. 81, 397-404.

Zheng, H., Hanaki, K., Matsuo, T., 1994. Production of nitrous oxide gas during nitrification of waster water. Water Sci. Technol. 30 (6), 133-141.

Zhou, Y., Lim, M., Harjono, S., Ng, W.J., 2012. Nitrous oxide emission by denitrifying phosphorus removal culture using polyhydroxyalkanoates as carbon source. J. Environ. Sci. 24, 1616-1623. 